\title{
Impact of Cooperatives in Financial Inclusion \& Comprehensive Development
}

\author{
P. Lakshmi* ${ }^{*}$ S. Visalakshmi \\ Department of Management Studies National Institute of Technology, Trichy \\ *Corresponding author: plakshmi@nitt.edu
}

Received June 09, 2013; Revised July 31, 2013; Accepted August 01, 2013

\begin{abstract}
The promotion of an inclusive financial system is considered a policy priority in many countries. Financial inclusion is important for improving the living conditions of poor farmers, rural non- farm enterprises and other vulnerable groups. While the importance of financial inclusion is widely recognized, there is lack of assessment of the extent of financial inclusion based on credit flow to small borrowers in Indian economy. The liberalized, increasingly global, market driven economy of India today, has failed to facilitate inclusive growth. This paper attempts to fill this gap by evaluating the extent of financial inclusion and emphasises the active participation of cooperatives as important tools of financial inclusion in India.
\end{abstract}

Keywords: financial inclusion, Indian economy, inclusive growth, cooperative banks, AFC - Kenya

Cite This Article: Lakshmi, P., and S. Visalakshmi, "Impact of Cooperatives in Financial Inclusion \& Comprehensive Development.” Journal of Finance and Economics 1, no. 3 (2013): 49-53. doi: 10.12691/jfe-1-3-4.

\section{Introduction}

The Committee on Financial Inclusion in India headed by Dr. C. Rangarajan [2], has defined Financial Inclusion as,

"The process of ensuring access to financial services and timely and adequate credit where needed by vulnerable groups such as weaker sections and low income groups at an affordable cost".

Financial Inclusion is both a crucial link and a substantial first step towards achieving inclusive growth. Financial Inclusion should include access to financial products and services like Bank accounts - check in account, Immediate Credit, Savings products, Remittances \& Payment services, Insurance - Healthcare, Mortgage, Financial advisory services \& Entrepreneurial credit. The Indian Government has a long history of working to expand financial inclusion. Nationalization of the major private sector banks in 1969 was a big step. In 1975 GOI established Regional Rural Banks with the same aim. It encouraged branch expansion of bank branches especially in rural areas. The RBI guideline to banks shows that $40 \%$ of their net bank credit should be lent to the priority sector. This mainly consists of agriculture, small scale industries, retail trade etc. More than $80 \%$ of our population depends directly or indirectly on agriculture. So $18 \%$ of net bank credit should go to agriculture lending. Recent simplification of KYC norms are another milestone.

Yet, banks are fighting to fulfill the Financial Inclusion dream. The main reason is that the products designed by the banks are not satisfying the low income families. In the first-ever Index of Financial Inclusion to find out the extent of reach of banking services among 100 countries,
India has been ranked 50. Only 34\% of Indian individuals have access to or receive banking services.

The list of financially excluded Indian individuals includes mainly the underprivileged section in rural and urban areas like farmers, small vendors, agricultural and industrial labourers, people engaged in un-organised sectors, unemployed persons, women, children, senior citizens \& physically challenged people.

The main reason for financial exclusion is the lack of a regular or substantial income. In most of the cases people with low income do not qualify for a loan. The proximity of the financial service is another fact. The loss is not only the transportation cost but also the loss of daily wages for a low income individual. Most of the excluded consumers are not aware of the bank's products, which are beneficial for them. Getting money for their financial requirements from a local money lender is easier than getting a loan from the bank. Most of the banks need collateral for their loans. It is very difficult for a low income individual to find collateral for a bank loan. Moreover, banks give more importance to meeting their financial targets. So they focus on larger accounts. It is not profitable for banks to provide small loans and make a profit.

\section{Financial Inclusion in India}

\subsection{Financial Inclusion - Steps Taken}

The Report of the Commission on Financial Inclusion recommends the setting up of a National Rural Financial Inclusion Plan with a target of providing access to financial services to at least 50 per cent $(50.77 \mathrm{mn})$ of excluded Indian rural households by 2012 and the remaining by 2015 . In order to increase this number the 
Reserve Bank of India and the Government of India have taken innovative steps. RBI's Contribution has led to developments in banking services like Overdraft facility in Saving Bank Accounts, Liberalised branch expansion, Liberalised policy for ATM, Introducing technology products and services, Pre-Paid cards, Mobile Banking, as well as allowing Regional Rural Banks / Co-operative banks to sell Insurance and Financial Products, Financial Literacy Program, Creation of Special Funds, etc.

One of the reasons for opening new branches of Regional Rural Banks is to make sure that the banking service is accessible to the poor. Other steps include encouraging Self Help Groups in excluded regions, measures for urban micro-finance and separate category of Micro Finance Institutions, Regional Rural Banks to extend banking services to unbanked areas \& Use of Primary Agricultural Credit Societies (PACS) and other co-operatives as Banking Channels and co-operatives to adopt group approach for financing excluded groups.

But from various estimate sources and surveys it is evident that still $50 \%$ of loans are to meet the emergency rather than for business needs. Even rich people are excluded, Even rich people have to depend on noninstitutional sources for loan purposes. Financial Exclusion persists also because of Absence of Technology, Absence of reach and coverage, Absence of Delivery Mechanism, Not having a Business model and the like. In the present scenario active participation of cooperative banks in the process of Financial Inclusion becomes inevitable because globally, countries focus on Inclusive Growth only through capitalizing the penetration advantage of cooperatives.

\subsection{Scope of Cooperative Societies Worldwide}

In the United States, 4 in 10 individuals is a member of a co-operative bank (40\%). Co-operative Banks in Europe have over 150 millions clients (one third of the EU population), 60,000 banking desks, 50 million members. In France, 21,000 co-operatives provide jobs to 700,000 people. In Germany, 8,106 co-operatives provide jobs for 440,000 people. Co-operative Banks in Europe are responsible for $74 \%$ of the meat products, $96 \%$ of dairy products, $50 \%$ of the egg production, $34 \%$ of forestry products \& $34.2 \%$ of the total deposits in banks. In Korea agricultural co-operatives have a membership of over 2 million farmers (90\% of all farmers) , an output of US\$11 billion. The Korean fishery co-operatives also report a market share of 71\%. In India, over 239 million people are members of a co-operative. In Japan, the agricultural cooperatives have $91 \%$ of all Japanese farmers in membership. China has 180 million members. Malaysia has 5.4 million members which is $20 \%$ of the population. Japan around 1 in 5 of all Japanese households belongs to a local retail co-op and $90 \%$ of all co-op members are women. In Singapore, consumer co-operatives hold 55\% of the market in supermarket purchases and have a turnover of USD 700 million. In Singapore, 50\% of the population (1.6 million people) are members of a cooperative.

\subsection{Co-operatives Create Employment}

Co-operatives provide over 100 million jobs around the world, 20\% more than multinational enterprises. In Canada, co-operatives and credit unions employ over 160,000 people. In Colombia, the co-operative movement provides 109,000 jobs which is $23 \%$ of jobs in the health sector, $18 \%$ of the jobs in the transport sector, $13 \%$ in the worker/industrial sector, $11 \%$ in the financial sector and $9 \%$ in the agricultural sector.

\subsection{Demographic Profile of India}

The Demographics of India are overall remarkably diverse. India's population of approximately over 1.13 billion people comprises nearly one-sixth of the world's population. India is basically an agrarian economy with $72 \%$ of its total population residing in rural areas. India is having huge opportunity since it is geographically diverse and major part of our economy is undeveloped so there is a great scope. Major problem of India is related with population. In case of industry, limited capacity can't serve greater employment demand.

\subsection{Growth of Cooperatives in India}

National Cooperative Development Corporation (NCDC) was established in 1963 under NCDC Act 1962 to promote production, marketing and export of agricultural produce. Today, Cooperatives cover each \& every village of India. Cooperatives account for $46 \%$ of Agriculture Credit disbursement, $36 \%$ of fertilizer distribution, $59 \%$ of Sugar production, 32\% of Wheat procurement \& $65 \%$ of Storage facility. In fertilizer production and distribution the Indian Farmers Fertiliser Cooperative (IFFCO) commands over 35 percent of the market with more than 50 million farmers associated with it. In the production of sugar the cooperative share of the market is over 58 percent and in the marketing and distribution of cotton they have a share of around 60 percent. The cooperative sector accounts for 55 percent of the looms in the hand-weaving sector. Cooperatives process, market and distribute 50 percent of edible oils. Dairy cooperatives operating under the leadership of the National Dairy Development Board and through 15 state cooperative milk marketing federations has now become the largest producer of milk in the world.

\subsection{Grey Areas of Indian Cooperative Sector}

Poor infrastructure, Lack of awareness, Lack of quality management, Over-dependence on government, Dormant membership, Non-conduct of elections, Lack of strong human resources policy, Neglect of professionalism, Restricted coverage are some of the gloomy areas of Indian Cooperatives. Cooperatives are also unable to evolve strong communication and public relations strategies which can promote the concept of cooperation among the masses.

Financial inclusion is a great step to alleviate poverty in India. But to achieve this, the government should provide a less perspective environment in which cooperative banks are free to pursue the innovations necessary to reach low income consumers and still make a profit. Rural Financial service providers should learn more about these consumers and new business models to reach them. In this 
perspective, a case study of the success of Kenyan Cooperative Bank- Agricultural Finance Corporation, through adaptation of innovative business models would be relevant. This is discussed in the subsequent section.

\section{Agricultural Finance Corporation (AFC) KENYA}

\subsection{About KENYA}

\section{About KENYA}

- The Kenyan economy is agricultural based.

- The Agricultural Sector directly contributes to $26 \%$ of GDP and a further 27\% through linkages with the manufacturing, distribution and service related sectors and it accounts for $60 \%$ of all export earnings.

- $75 \%$ of agricultural produce is from small holder farmers.

Kenyan co-operatives put their contribution to GDP at $45 \%$ with $31 \%$ of national savings and deposits. They have $70 \%$ of the coffee market, $76 \%$ of the dairy, $90 \%$ of pyrethrum and $95 \%$ of cotton. In Kenya 1 in 5 is a member of a co-operative or 5.9 million and 20 million Kenyans directly or indirectly deriving their livelihood from the Co-operative movement.

\subsection{Agricultural Finance Corporation}

Agricultural Finance Corporation is a Government owned Non-Bank Development Finance Institution (NBDFI). It is the Government's main vehicle for credit delivery to agricultural and rural sector. It was established in 1963 under a specific legal framework. Mandate of AFC is to assist in the development of agriculture and agricultural industry by making loans to Farmers, Incorporated group representatives, Private companies and public bodies, Local authorities and other persons engaging in agriculture and agricultural allied activities.

\subsection{Challenges Faced by AFC in Rural and Agricultural Finance Service Provision}

The volume of transactions was very low due to limited pieces of land/agricultural projects. Income was too meager from such low value transactions. Dispersion of farming enterprises was rendering them very costly to administer through follow-ups and projects monitoring. Long gestation periods of most agricultural projects like Sugarcane, Tea, Coffee etc. caused a challenge especially when resources are scarce as huge capital outlays are tied up. Subsequent shortages pushed up the cost of credit due to a high demand. Seasonality of agricultural credit demand was dictated by seasonal nature of enterprises. The flip side was a strain on farmers to undertake their financial obligations during off seasons. Due to the high seasonal nature of rain fed agriculture, huge investments were incurred during planting seasons and relatively low during other times of the year generating a pattern of high credit demand during planting seasons.

Other major challenges include High risk (vagaries of weather, pests, fluctuating and often unpredictable produce prices and markets etc), Lack of insurance, Limited availability or lack of realizable collateral,
Multiple demands on same source of income (family consumption, medical requirements, clothing, school fees etc), Misconception by beneficiaries on public institutions supplied financial services mainly credit -assistance or credit? Most often construed to be Grants, Over-reliance on land as collateral which had numerous social and political connotations, 'Debtor friendly' legal system that was too expensive and time consuming, Effects of past loan waivers inculcating a culture of "wait-and-see" to loan servicing (for AFC), Willful and strategic default by loan-beneficiaries and Poor/lack of timely response to changing operating environment.

AFC faced with the abovementioned endless list of challenges in rural finance that is very much prevalent in the Indian context too, adopted a number of innovative strategies to address them. Some of these are discussed as follows.

\subsection{Innovation to Address Rural Finance Challenges}

\subsubsection{Group Finance}

AFC adopted group financing concept to reach Small scale farmers who require small credits who do not have requisite collaterals by improving access to produce markets and used peer pressure to collect.

\subsubsection{Wholesale Financing}

AFC channeled credit funds through Non Governmental Organizations, etc. to increase outreach and reduce lending costs, through peer pressure improved project implementation, loan recovery and reduced moral hazards.

\subsubsection{Business Partnerships}

AFC established partnership with institutions in sectors that did not have lending structure. AFC raised loanable funds, engaged in Direct lending to specific sub-sectors, and deviated clients perception of public funds ( to reduce moral hazards). Currently AFC is in business partnerships with Kenya Sugar Board, Coffee development Fund \& Government ministries.

\subsubsection{Contract Farming Financing}

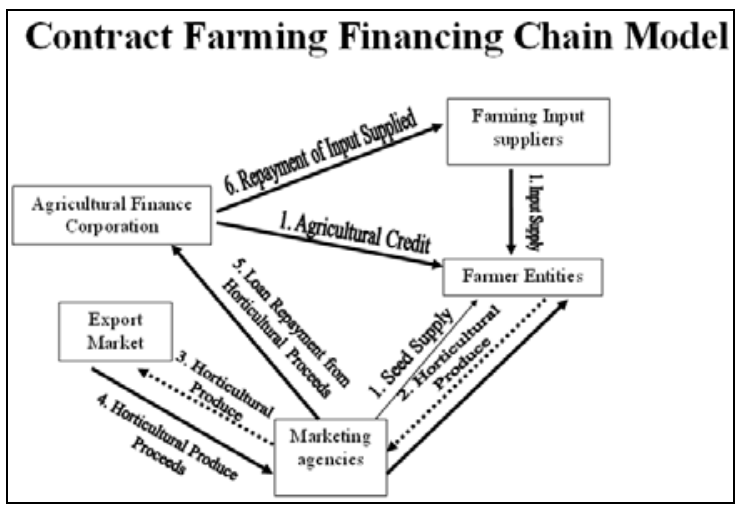

Figure 1. Contract farming financing Chain Model

AFC engaged in Financing farmers with specified produce markets and formulizing repayment orders to ensure markets for produce and Loan repayment through sale of proceeds (Figure 1). Thus AFC could reach many 
small holder farmers producing fresh produce for export market. Loans were short term revolving facility. Also financed were other non export food crops under the umbrella of contract farming

\subsection{Loan Guarantees}

The AFC partners with development agencies in agriculture that can offer credit guarantee to small holder farmers and input suppliers. Through a partnership with an NGO they have been able to finance young trained rural based agricultural input stockists (Figure 2). This increases application of quality inputs, increase yields and employment.

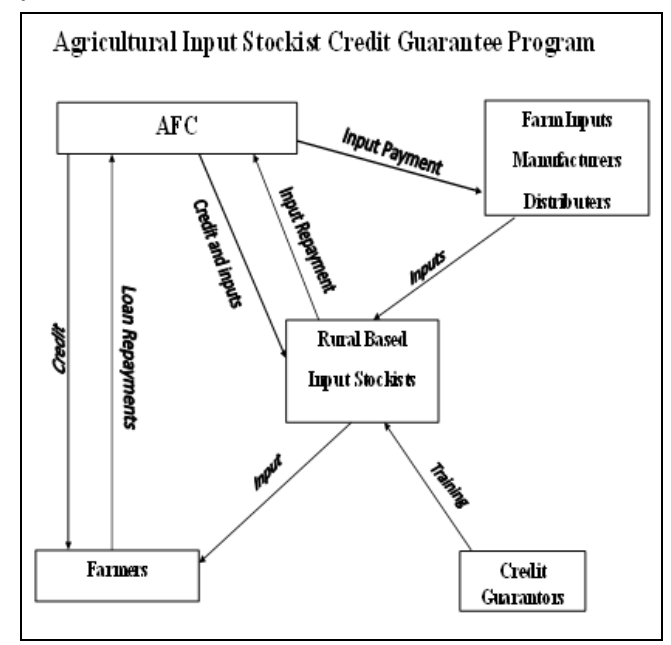

Figure 2. Agricultural Input Stockist Credit Guarantee Program

\subsection{Produce Based Financing}

AFC enters into partnerships with agri-business organization that work with small scale farmers. Provide finances to small scale farmers on the strength of production contracts with marketing agent (Figure 3). No collateral will be required as farmers' co-ops and contracts with marketing body will be adequate. Loan funds revolved amongst Co-op members which resulted in Low capital requirement from lender. AFC embraced new technology and installed new banking software to offer online and real time transactions processing to reduce on cost of transaction. Other related products that are rolled out are Customer relationship/savings accounts, Electronic money remittances, Electronic loan repayment and disbursements. Customer Delight - Access information on their accounts $24 \times 7$ all year round.

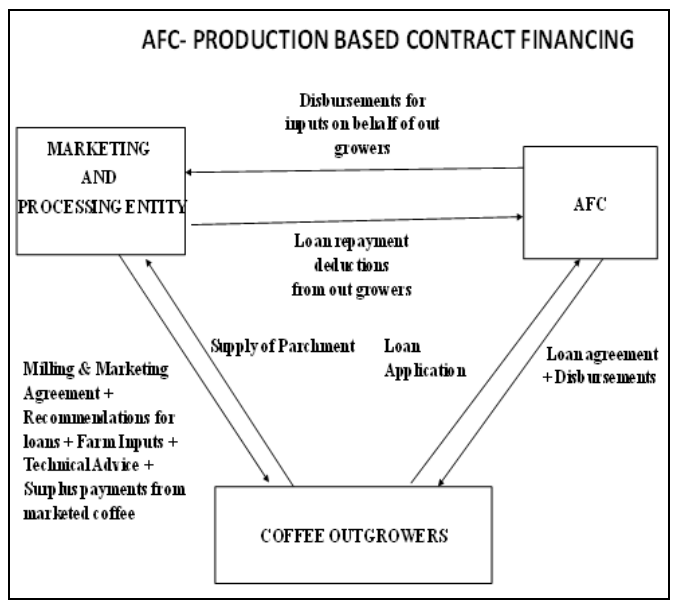

Figure 3. AFC- Production Based Contract Financing

\subsection{Fruits of the Innovations}

The innovations have enabled the AFC to Offer credit all year round, Attract new partners and funding, Improve institution's image to public, donor and Government, Increased outreach from about 10,000 farmers five years ago to over 35,000 directly and over 100,000 indirectly through co-ops and partnerships.

\section{Comprehensive Development in India}

\subsection{Pre-requisites for the Success of Financial Inclusion in India through Cooperatives}

The Kenyan AFC case study clearly brings to light that the success of financial inclusion in India is next to impossible without the participation of Cooperatives. The prerequisites for this success to become a reality requires Appropriate Technology, Appropriate and Efficient Delivery model, Mainstream banks' determination and involvement, Strong Collaboration among Banks, Technical Service Provider, Business Channel Services , Involvement of all, especially the state administration at grass-root level and Liberalisation of Business Correspondents model

\subsection{Know Your Customer (KYC) as a Tool to Grow Your Customer (GYC)}

Currently Know your customer (KYC) norms are applicable to all types of customer a/cs. It deals with not only to identify the customer but also to understand the activities of the customer, and to ensure that the operation in the customer account/s is/are for genuine purpose. Application of KYC norms has become important due to various reasons. In view of many issues on account of drugs smuggling, money laundering, terrorist activities, arms dealing, etc., banks need to be careful in dealing with their clients.

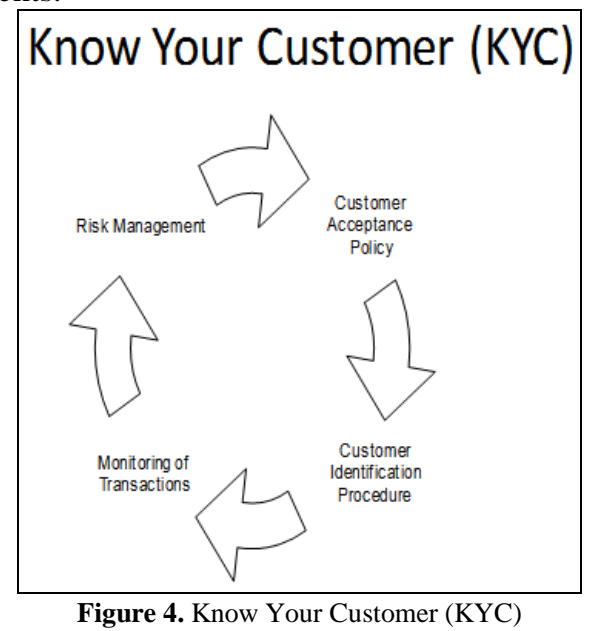

Financial inclusion mainly focuses on the poor who do not have formal financial institutional support and getting them out of the clutches of local money lenders. As a first step towards this, some of our banks have now come forward with general purpose credit cards and artisan credit cards which offer collateral-free small loans. With the directive from RBI, our banks are now offering "No Frill" Accounts to low income groups. These accounts either have a low minimum or nil balance with some 
restriction in transactions. The individual bank has the authority to decide whether the account should have zero or minimum balance. With the combined effort of financial institutions, six million new 'No Frill' accounts were opened in the period between March 2006-2007. Banks are now considering Financial Inclusion as a business opportunity in an overall environment that facilitates growth. The RBI has simplified the KYC (Know your customer) norms for opening a 'No frill' account. This will help the low income individual to open a 'No Frill' account without identity proof and address proof.

In such cases banks can take the individual's introduction from an existing customer whose full KYC norm procedure has been completed. And the introducer must have a satisfactory transaction with the bank for at least 6 months. This simplified procedure is available to those who intend to keep a balance not exceeding Rs.50,000 in all accounts taken together. With this facility we can channel the untapped, considerable amount of money from the low income group to the formal economy. Banks are now permitted to utilize the service of NGOs, SHGs and other civil society organizations as intermediaries in providing financial and banking services through the use of business facilitator and business correspondent models.

\section{Conclusion}

Development of cooperative banks into safe and vibrant entities requires them to be efficient. Banking Technology is in place for urban banking system. Cooperative Banks should therefore be proactive about transferring this technology into an opportunity. The current market trend and policy makers suggest that for better survival for banks, size is one of the important factors. A combination of financial restructuring and institutional reform can only help cooperative banks to improve the efficiency. The provision of uncomplicated, small, affordable products will help to bring the low income families into the formal financial sector. Banks have limitations to reach directly to the low income consumers. Correspondents can be considered to be an excellent channel which banks can use to distribute their product information. Educating the consumers about the financial benefits and products of banks which are beneficial to low income groups will be a great step to tap their potential.

Efficiency is measured by the ratio of output to input, where a larger value of this ratio indicates better performance. The performance of a cooperative bank is conceptualized as the extent to which the bank is able to utilize its resources to generate business transactions and it is measured by an efficiency ratio. Technical Efficiency (TE) is considered for analyzing the performance of the banks. TE refers to the relationship between scarce factor inputs and outputs of goods and services. Scale efficiency is that component of Technical Efficiency that can be attributed to the size of operation. It has been observed that the Pure Technical Efficiency of Co-operative Banks during the current years has shown a decreasing trend. A similar trend is observed in the case of Scale Efficiency.

Changes in the corporate culture will also bring sustainable efficiency and thereby cooperatives can compete with strong private players. Professionalism in the management of the cooperative enterprises will upgrade the quality of the staff with latest developments and also develop a proper and cordial relationship between the managers and members of board of directors. There must be proper and continuous training for both cooperative leaders and professional executives. There are a number of agricultural commodities like rice, sugar, fruits, vegetables; spices etc. that have strong competitive advantage in export markets. Agricultural cooperatives can take this advantage in foreign market. The leadership with vision, dedication, commitment and above all innovative approach can help in preserving Cooperative Identity in an Era of Competition.

\section{References}

[1] Dr. K.C.Chakrabarty, Deputy Governor, RBI "Pushing Financial Inclusion - Issues, Challenges and Way Forward”, Presentation at $20^{\text {th }}$ SKOCH Summit 2009, Mumbai on July 17, 2009.

[2] Rangarajan Committee (2008), Report of the Committee on Financial Inclusion, Government of India.

[3] "Innovations in Addressing Rural Finance Challenges In Africa”Afraca Technical Workshop, 26 ${ }^{\text {th }}$ November 2008 www.afraca.org.

[4] Dr. K. Sriharsha Reddy, "A Study on Extent of Financial Inclusion among Small Borrowers in Andhra Pradesh”, CLEAR International Journal of Research in Management, Science and Technology Vol-1 No-1 Jan-Jun 2011.

[5] Mohan Rakesh (2006), "Economic growth, Financial Deepening and Financial Inclusion”, Address at the Annual Bankers' Conference 2006, Hyderabad.

[6] Basant Kumar \&BrajarajMohanty, "Financial inclusion and inclusive development in SAARC countries with Special Reference to India” Vilakshan, XIMB Journal of Management Vol VIII Issue 2 September 2011.

[7] World Bank (2006), "Micro Finance in South Asia- Towards Financial Inclusion of the Poor".

[8] AroraRashmiUmesh, (2010), “Measuring Financial Access”, Griffith University, Australia, June. 